\title{
Density of Aedes Aegypti Larves Based on Knowledge, Attitude and Action of Terminal Management in Daya Regional Terminal Kota Makassar
}

\author{
Rusydi Indra ${ }^{1}$, Erniwati Ibrahim ${ }^{1}$, ApikIndarty Moedjiono ${ }^{2}$, Syamsuar $\mathbf{M}^{\mathbf{1}}$, Agus Bintara \\ Birawida $^{1}$, Masni ${ }^{2}$
}

${ }^{1}$ Environmental Health Section, Faculty of Public Health, Hasanuddin University, Indonesia

${ }^{2}$ Department of Biostatistics and Reproductive Health, Faculty of Public Health, Hasanuddin

University, Indonesia

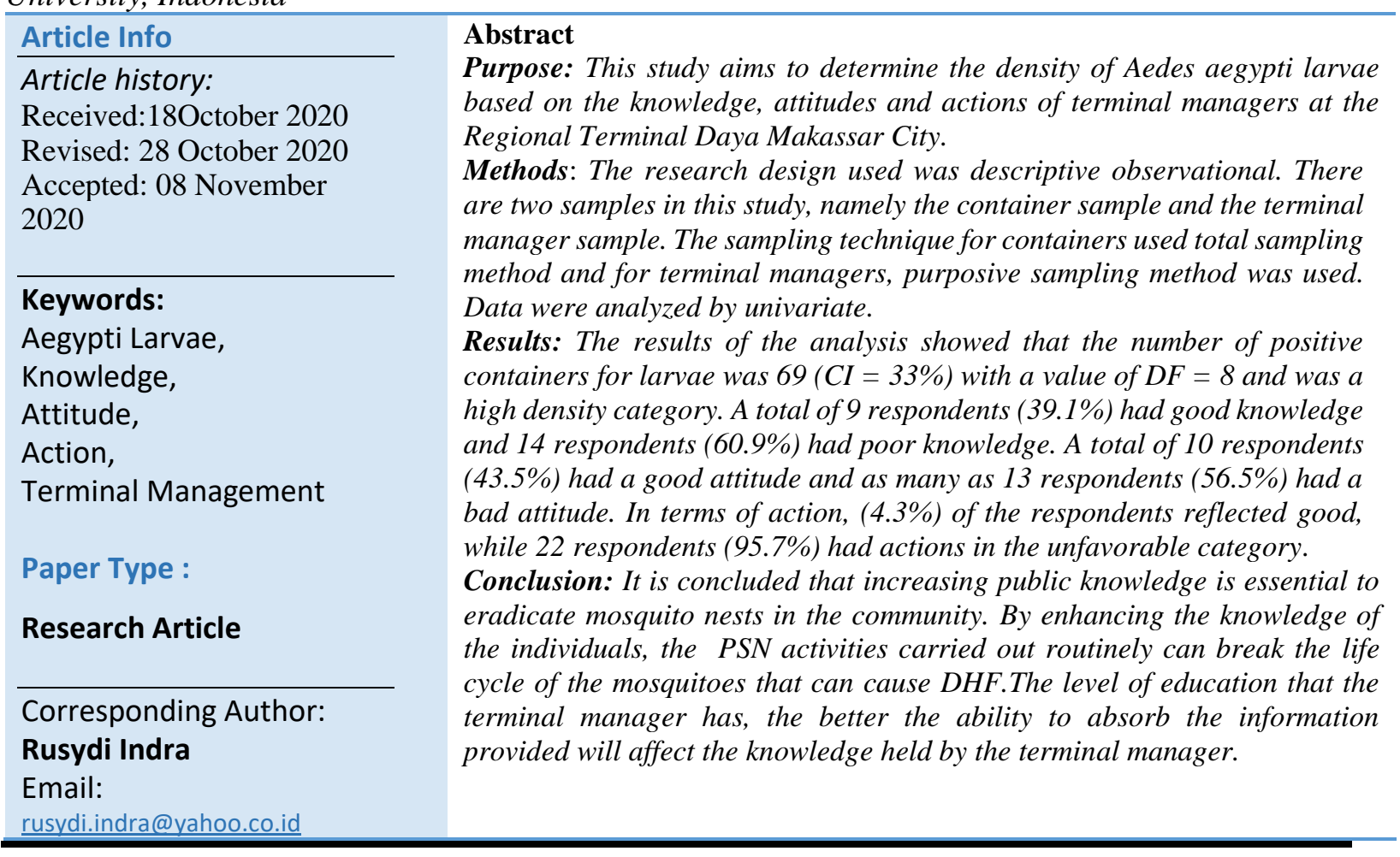

\section{Introduction}

The main factors for the risk of disease transmission stem from poor community behavior and environmental conditions that do not meet health requirements, especially environmentally based diseases, one of which is Dengue Hemorrhagic Fever (DHF). It is estimated that Asia accounts for $70 \%$ of dengue infection, India alone accounts for $34 \% ; 14 \%$ occurred in America, more than half occurred in Brazil and Mexico; 16\% occur in Africa, and only $0.2 \%$ in Oceania (Alvarado-Castro et al., 2017).

In Indonesia in 2018, there were 65,602 cases, with the number of deaths as many as 467 people. This number decreased from the previous year, namely 68,407 cases and the number of deaths as many as 493 people. This number decreased from the previous year, namely 68,407 cases and the number of deaths as many as 493 people. Meanwhile, the coverage of the larva free rate (ABJ) in 2018 was $31.5 \%$, a decrease compared to 2017 which was $46.7 \%$. $\mathrm{ABJ}$ is the expected output from the activities of the 1 Home 1 Jumantik 
Movement (G1R1J) (Ministry of Health, 2019).

The research study by Arsin et al (2013) on the analysis of environmental factors and the movement of Mosquito Nest Eradication (PSN) on the density of Aedes aegypti mosquito larvae and the incidence of dengue fever in Makassar City revealed that the type of container, temperature, humidity and $\mathrm{pH}$ affected the presence of Aedes aegypti larvae. In addition, there was an increase in ABJ after the intervention of PSN DBD (3M Movement and Abatization) (Arsin, Ibrahim, Ane, \& Ishak, 2013). Human factors in the form of behavior and community participation that are still lacking in Mosquito Nest Eradication (PSN) activities as well as factors for population growth and factors for increasing population mobility which are in line with improved transportation facilities are also one of the causes of the spread of the dengue virus getting easier and wider (Arsin, 2013). PSN activities can be carried out by means of physical, biological, chemical and through community empowerment. Community empowerment efforts by carrying out the 3M Plus PSN activities (draining, closing water reservoirs and recycling / reusing used goods) and added (Plus) such as: sprinkling larvae that kill larvae, raising larvae eating fish, replacing water in pots / flower vases and others (Ministry of Health, 2016).

One of the targets for the guidance and supervision of vector control implementation which is a potential place for dengue transmission is public places (TTU), places where people from various regions gather, one of which is the terminal. The meeting of a group of routes has resulted in a lot of movement that occurs inside the terminal so that the activities in the terminal are varied, and it is thus possible to transmit diseases originating from vectors, especially mosquitoes. The PSN also needs to be carried out in TTU, especially terminals around residential areas (Indahsari, 2018; Ministry of Health, 2010). This is in line with the mandate of Government Regulation Number 66 of 2014 concerning Environmental Health that the manager, organizer or person in charge of TTU is obliged to make efforts to control vectors and animals that carry disease, including controlling mosquito larvae which are carried out periodically and continuously(President of the Republic of Indonesia, 2014).

Based on the results of research conducted by Batara (2018), it is found out that the terminals in South Sulawesi, one of which is the Regional Daya Terminal, are tarnished with a lot of garbage scattered around the terminal. Besides, the clogged SPALs also cause standing water in the rainy season which has the potential to become a breeding ground for mosquitoes(Batara, 2018). In addition, data from the Makassar City Health Office, the Regional Daya Terminal, indicate that the districts, namely Biringkanaya District, have the highest incidence of dengue fever. The results of preliminary observations carried out also showed that there were mosquito breeding sites which were marked by the presence of mosquito larvae in several containers inside the toilets at the terminal public facilities. These sites might be a risk factor for dengue transmission.

\section{Methods and Procedures}

The type of research used in this research is descriptive using observational methods to describe the density of Aedes aegypti larvae at the Regional Terminal Daya Makassar City based on the knowledge, attitudes and actions of terminal managers. This research was 
conducted at the Daya Regional Terminal, Makassar City, South Sulawesi Province in 2020. The population in this study were all containers and all terminal managers in the Daya Regional Terminal. The samples in this study were containers and terminal managers consisting of terminal employees in the terminal management section, terminal cleaners and toilet guards. The sampling technique for container samples is the total sampling method, and for training participants using purposive sampling method.

Primary data related to knowledge and attitudes were obtained using a questionnaire regarding PSN. PSN action is obtained from direct observation of respondents, and the density data of Aedes aegypti larvae were obtained from direct observation on the container using the visual method with the aid of a flashlight and an observation sheet. The size used is the Container Index (CI). Secondary data were obtained from the South Sulawesi Provincial Health Office, Makassar City Health Office and Puskesmas and PD. Makassar Metro Terminal. The data analysis used in this study is univariate analysis to describe the frequency distribution of each variable.

\section{Results and Discussion}

\section{Respondent Characteristics}

Table 1: Distribution of Respondent Characteristics Based on Occupation / Position, Age Group, Gender and Last Education

\begin{tabular}{|c|c|c|c|}
\hline \multicolumn{2}{|r|}{ Variable } & \multirow[t]{2}{*}{$\mathbf{n}$} & \multirow[t]{2}{*}{$\%$} \\
\hline 1) & Employment/Position & & \\
\hline & Terminal Employees & 7 & 30,4 \\
\hline & Janitor & 13 & 56,5 \\
\hline & Toilet Guard & 3 & 13,1 \\
\hline \multirow[t]{6}{*}{ 2) } & Age & & \\
\hline & $<21$ Years & 1 & 4,3 \\
\hline & $21-30$ Years & 1 & 4,3 \\
\hline & $31-40$ Years & 8 & 34,8 \\
\hline & $41-50$ Years & 9 & 39,1 \\
\hline & $>50$ Years & 4 & 17,4 \\
\hline \multirow[t]{3}{*}{ 3) } & Sex & & \\
\hline & Male & 15 & 65,2 \\
\hline & Female & 8 & 34,8 \\
\hline \multirow[t]{7}{*}{ 4) } & Last Education & & \\
\hline & Higher Education & 5 & 21,7 \\
\hline & Graduated from High & 12 & 52,2 \\
\hline & School & & \\
\hline & Graduated from Junior & 4 & 17,4 \\
\hline & School & & \\
\hline & $\begin{array}{l}\text { Graduated from Elementary } \\
\text { school }\end{array}$ & 2 & 8,7 \\
\hline
\end{tabular}

Copyright (C) 2020, Journal of Scientific Research in Medical and Biological Sciences (JSRMBS), Under 
Based on Table 1, it can be seen that of the 23 people the number of respondents, respondents with positions / jobs as terminal employees in the management section were 7 people $(30.4 \%), 13$ cleaners $(56.5 \%)$ and 3 toilet guards. people $(13.1 \%)$, there were 9 people (39\%) aged 41-50 years and the least were respondents aged <21 years and those aged 21-30 years, namely 1 person each $(4.3 \%)$. Respondents were male - 15 people $(65.2 \%)$ and female as many as 8 people $(34.8 \%)$. Respondents who have the latest education in tertiary education are 5 people $(21.7 \%), 12$ people have graduated from high school $(52.2 \%), 4$ people have graduated from junior high school $(17.4 \%)$ and 2 people have graduated from elementary school $(8.7 \%)$.

Table 2: Distribution of the presence of Aedes aegypti larvae in Containers at the Daya Regional Terminal

\begin{tabular}{ccc}
\hline Larvae Density & $\mathbf{n}$ & $\boldsymbol{\%}$ \\
\hline Positive & 69 & 33 \\
Negative & 140 & 67 \\
\hline Total & $\mathbf{2 0 9}$ & $\mathbf{1 0 0}$ \\
\hline
\end{tabular}

Source: Primary Data, 2020

Based on the table above, it is known that of the 209 containers in the Regional Power Terminal of Makassar City, both TPA and Non TPA, the number of positive containers for larvae is $69(33 \%)$ and containers that are negative for larvae are 140 pieces $(67 \%)$.

Table 3: Distribution of Aedes aegypti Larvae Density Based on Container Type at the Daya Regional Terminal

\begin{tabular}{cccccc}
\hline Type of Container & $\begin{array}{c}\text { Number of } \\
\text { Container }\end{array}$ & $\begin{array}{c}\text { Containers } \\
\text { Positive } \\
\text { Larva }\end{array}$ & \% & $\begin{array}{c}\text { CI } \\
\text { Value }\end{array}$ & DF \\
\hline Bathtub & 17 & 4 & 1,9 & & \\
Tandon & 3 & 1 & 0,5 & & \\
Bucket & 18 & 1 & 0,5 & & 8 \\
Drum & 4 & 1 & 0,5 & 33 & \\
Dispenser & 23 & 3 & 1,4 & & \\
Refrigerator & 11 & 1 & 0,5 & & \\
Used tires & 136 & 58 & 27,8 & & \\
\hline Total & $\mathbf{2 0 9}$ & $\mathbf{6 9}$ & $\mathbf{3 3}$ & & \\
\hline
\end{tabular}

Source: Primary Data, 2020

Based on the table above, it is known that the types of containers found to be larvae are the highest in used tires as many as 58 pieces (27.8\%) and the lowest in containers, buckets, drums and refrigerators -1 each $(0.5 \%)$. The total number of positive containers for larvae was 69 , so that the CI value $=33 \%$ with the value of $\mathrm{DF}=8$. 
Table 4: Distribution of Respondents' Knowledge, Attitudes and Actions Regarding PSN

\begin{tabular}{cccc}
\hline Variable & Kategori & n & \% \\
\hline \multirow{2}{*}{ Knowledge } & Good & 9 & 39,1 \\
& Less Good & 14 & 60,9 \\
\hline \multirow{2}{*}{ Attitude } & Good & 10 & 43,5 \\
& Less Good & 13 & 56,5 \\
\hline \multirow{2}{*}{ Action } & Good & 1 & 4,3 \\
& Less Good & 22 & 95,7 \\
\hline
\end{tabular}

Source: Primary Data, 2020

Based on table 4, it is known that of the 23 respondents, the majority of respondents had poor knowledge, namely 14 respondents $(60.9 \%)$. The majority of respondents had an attitude in the unfavorable category, as many as 13 respondents $(56.5 \%)$. And the majority of respondents had actions in the unfavorable category as many as 22 respondents $(95.7 \%)$.

Table 5: Distribution of Knowledge Relationships and Respondents' Attitudes Regarding PSN

\begin{tabular}{cccccccc}
\hline \multirow{2}{*}{ Crosstab } & Categocy & Good & $\%$ & $\begin{array}{c}\text { Less } \\
\text { Good }\end{array}$ & $\%$ & \multirow{2}{*}{ Total } & \% \\
\cline { 3 - 7 } & & & & & & & \\
\hline \multirow{2}{*}{ Knowledge } & Good & 8 & 34,8 & 1 & 4,3 & 9 & 39,1 \\
& Less Good & 2 & 8,7 & 12 & 52,2 & 14 & 60,9 \\
\hline \multicolumn{2}{c}{ Total } & 10 & 43,5 & 13 & 56,5 & 23 & 100 \\
\hline
\end{tabular}

Source: Primary Data, 2020

Based on the table above, it is known that of the 23 respondents studied, the most respondents who had bad PSN knowledge also had bad PSN attitudes, namely 12 people (52.2\%) and the least respondents who had good PSN knowledge with PSN attitude is not good, namely 1 person $(4.3 \%)$.

Table 6: Distribution of Knowledge Relationships and Respondents' Actions Related to PSN

\begin{tabular}{|c|c|c|c|c|c|c|c|}
\hline \multirow[b]{2}{*}{ Crosstab } & \multirow[b]{2}{*}{ Category } & \multicolumn{4}{|c|}{ Action } & \multirow[b]{2}{*}{ Total } & \multirow[b]{2}{*}{$\%$} \\
\hline & & Good & $\%$ & $\begin{array}{l}\text { Less } \\
\text { Good }\end{array}$ & $\%$ & & \\
\hline \multirow{2}{*}{ Knowledge } & Good & 1 & 4,3 & 8 & 34,8 & 9 & 39,1 \\
\hline & Less Good & 0 & 0 & 14 & 60,9 & 14 & 60,9 \\
\hline \multicolumn{2}{|c|}{ Total } & 1 & 4,3 & 22 & 95,7 & 23 & 100 \\
\hline
\end{tabular}

Source: Primary Data, 2020

Based on the table above, it is known that of the 23 respondents studied, the most respondents who had bad PSN knowledge also had bad PSN actions, namely 14 people (60.9\%) 
and the least respondents who had good PSN knowledge with good PSN action, namely 1 person $(4.3 \%)$.

Table 5:Distribution of Respondents' Attitudes and Actions Relating to PSN

\begin{tabular}{cccccccc}
\hline \multirow{2}{*}{ Crosstab } & Category & \multicolumn{9}{c}{ Tindakan } & \multirow{2}{*}{ Total } & $\%$ \\
\cline { 3 - 7 } & & Baik & $\%$ & $\begin{array}{c}\text { Kurang } \\
\text { Baik }\end{array}$ & $\%$ & \\
\hline \multirow{2}{*}{ Attitude } & Good & 1 & 4,3 & 9 & 39,1 & 10 & 43,5 \\
& Less Good & 0 & 0 & 13 & 56,5 & 13 & 56,5 \\
\hline \multicolumn{2}{c}{ Total } & 1 & 4,3 & 22 & 95,7 & 23 & 100 \\
\hline
\end{tabular}

Source: Primary Data, 2020

Based on the table above, it is known that of the 23 respondents studied, the most respondents who had bad PSN attitudes also had bad PSN actions, namely 13 people (56.5\%) and the least respondents who had good PSN attitudes with good PSN action, namely 1 person $(4.3 \%)$.

\section{Discussion}

The density of Aedes aegypti larvae was measured using the container index (CI) value. The existence of containers plays a very important role in the density of Aedes larvae, because the more containers, the more breeding places and the denser the Aedes mosquito population. The denser the Aedes mosquito population, the higher the risk of being infected with the dengue virus with a faster spread time so that the number of dengue cases increases rapidly, which in turn results in an outbreak of dengue fever.

Based on the results of the study, it is known that of the 209 containers in the Regional Power Terminal of Makassar City, both TPA and Non TPA, 69 positive containers of larvae $(\mathrm{CI}=33 \%)$ were obtained with a value of $\mathrm{DF}=8$ and a high density category. The most common containers found for larvae are used goods such as used tires (56\%) at the terminal yard. This is because the drivers or terminal managers tend to collect used tires for resale. The used tires that have not been or are not sold are allowed to pile up and become a container for mosquito breeding.

The number of used tires that are positive for larvae is due to the fact that these used tires are non-TPA types. They cannot be controlled as garbage and are usually found outside the building. Whenever they are filled with rain water, they become a breeding ground for mosquitoes if it is not cleaned or buried. The large number of mosquito larvae on used tires is because Aedes aegypti mosquitoes prefer dark colored breeding places, protected from sunlight, wide open surfaces, not covered and filled with fresh and clear water and the inner surface of the tires which is rough causing mosquitoes to easily lay their eggs.

Apart from the existence of containers, another factor that influences the presence of larvae is the behavior of the PSN which consists of knowledge, attitudes and actions related to PSN from the terminal manager. The results of the study indicate that 9 of the respondents (39.1\%) were in a good category. The results of the knowledge from the questionnaire given to respondents reveal that almost half of the respondents knew about the mosquito that carries 
the dengue virus, the characteristics of the dengue mosquito. They also heard about PSN and $3 \mathrm{M}$ Plus. It is therefore assumed that the respondents' knowledge is influenced by the level of education. Based on the results of the study, it can be seen that most of the respondents with high school education (52.2\%) are well-aware of the danger of dengue and its causes.

The level of education is related to the ability to receive information from various sources. Moreover, DHF is not a new disease known in the community. A lot of information about DHF that they have heard either comes from electronic media, the environment they live in, health workers or through direct experience. With the high level of education owned by the terminal manager, the better the power of absorbing and receiving the information provided, affecting the knowledge possessed by the terminal manager. This is in line with research conducted by Kumaran et al (2018) which states that respondents with at least 6 years of education experience almost seven times the possibility of knowing that mosquitoes are vectors of dengue fever and are four times more likely to mention at least one mosquito breeding location (Kumaran et al., 2018).

Therefore, knowledge of the dangers of Aedes aegypti mosquitoes and dengue fever makes a person aware that PSN is a step that must be taken to prevent the occurrence of these diseases and motivate someone to do PSN properly (Al-Zurfi et al., 2015). This is in line with research conducted by Nani (2017) concerning the Relationship between PSN Behavior and the Presence of Aedes aegypti larvae at PulangPisau port, showing that there is a relationship between knowledge and the presence of Aedes aegypti larvae at PulangPisau Port (Nani, 2017). The research study by Purnianto et al (2019) also states that there is a relationship between knowledge and the presence of Aedes aegypti in the Buffer area at TanjungIntan Cilacap Port with a p value of 0.005 (Purnianto, Hestiningsih, \&Kusariana, 2019). From the research results, it can also be seen that as many as 8 respondents (34.8\%) had good knowledge but their actions were in the poor category. Therefore, good knowledge cannot guarantee having good behaviour as well, but it depends on one's own awareness. The low level of public awareness causes the high density of larvae (Ibrahim, Manyullei, \& Sumarni, 2019).

Attitude is a response or reaction that is still closed to a stimulus or object (Notoatmodjo, 2014). The results showed that there were 10 respondents $(43.5 \%)$ in good category. One component of attitude is the concept of an object. This concept is derived from knowledge. Individuals who have knowledge of an object influence an individual's opinion or judgment on that object. Thus knowledge and attitude are interconnected. So that knowledge of the dangers of Aedes aegypti mosquitoes and dengue disease makes a person aware and take attitudes and actions to carry out PSN.

This is in line with research conducted by Nani (2017) regarding the Relationship between PSN Behavior and the Existence of Aedes aegypti larvae at PulangPisau Port [(Nani, 2017)] shows that there is a relationship between attitudes and the presence of Aedes aegypti larvae at Pulang Pisau Port. Research by Purnianto et al (2019) also states that there is a relationship between the attitude and presence of Aedes aegypti in the Buffer area at TanjungIntan Cilacap Port with a p value of 0.005 (Purnianto et al., 2019). From the results of the study, it can be seen that 8 respondents $(34.8 \%)$ have good knowledge and they also have good attitudes. On the other hand, 12 respondents (52.2\%) have poor knowledge also have attitudes with poor categories. In addition, as many as 13 respondents (56.5\%) had 
unfavourable attitudes and actions. The attitude of the community is good but there are still larvae because people only respond well without any real application. In eradicating mosquito nests, they only receive and respond but do not make real applications, namely eradicating mosquito nests. Having good knowledge and attitude is not necessarily able to produce maximum results without real action.

Action is an activity or activity of people who are focused on something. It means that action is real behavior shown to a known object (Notoatmodjo, 2014). A person's actions are based on an assessment or opinion of what he / she knows, then acted upon and finally took the decision to do so (Kholid, 2012). The assessment of PSN actions in this study is based on observations made by researchers on terminal managers in the implementation of $3 \mathrm{M}$ plus activities, namely draining water reservoirs, closing water reservoirs tightly, recycling used items and periodically monitoring larvae. The results showed that as many as 1 respondent $(4.3 \%)$ whose actions were in the good category and as many as 22 respondents $(95.7 \%)$ had actions in the unfavorable category.

Knowledge of the dangers of Aedes aegypti mosquitoes and dengue disease makes a person aware that PSN is a step that must be taken to prevent the disease and motivate someone to do PSN properly. This is in line with a research study conducted by Sudarmika (2019) in which the results show that knowledge and attitude are significantly related to dengue fever mosquito eradication behavior because the p value $<\alpha(0.05)$ (Sudarmika, Maba, \&Widnyana, 2019). Hence, the existence of containers, environmental cleanliness and larva density are very dependent on PSN action which is one of the most effective ways to eradicate Aedes aegypti mosquito larvae through the $3 \mathrm{M}$ Plus movement. If PSN practices are good, the density of larvae can be reduced. In a research conducted by Ishak et al (2018), there was a relationship between the presence of Aedes aegypti larvae and the PSN DHF action. In addition, there is a relationship between Aedes aegypti larvae density and PSN DHF action (Ishaketal., 2019). The research study conducted by Nani (2017) also shows that there is a relationship between PSN practice and the presence of Aedes aegypti larvae at PulangPisau Port (Nani, 2017). Similarly, Purnianto et al (2019) states that there is also a relationship between action and the presence of Aedes aegypti larvae in the Buffer area at Tanjung Pelabuhan IntanCilacap with a $p$ value of 0.039 .

The results of the present study show that 8 respondents (34.8\%) had good knowledge but their actions were in the poor category. Likewise for attitude, as many as 9 respondents (39.1\%) had a good attitude but their actions were in the unfavorable category. This is because knowledge about the causes and ways of preventing dengue fever only reaches the level of knowing and understanding, as well as attitudes only reaching the level of acceptance and response. This is because the information obtained is still not clear and there are also many factors that influence individuals to take appropriate action according to the knowledge and attitudes they have.

The lack of action and the presence of larvae are caused by the community's lack of concern for the surrounding environment (Singhetal., 2011) as well as a lack of self-awareness. The low level of awareness of the community causes the high density of larvae (Ibrahim et al., 2019). For example, it is the habit of drivers and terminal managers to collect used tires for resale. Consequently, the used tires that have not been or are not sold are allowed to pile up 
and become a container for mosquito breeding. Inconsistent and continuous actions can also be the cause of the high density of larvae. In general, the act of draining a water reservoir is only carried out in a reservoir that is usually used daily. Apparently, the places where people are not aware of piles of used tires, dispensers and refrigerators that cause standing water, are prone to become mosquito breeds. Therefore, government efforts are needed to increase public awareness so that there is an increase in behaviour in eradicating mosquito nests in the community. The PSN activities carried out routinely can break the life cycle of mosquitoes that cause DHF.

\section{Conclusion}

Based on the results of this study, it can be concluded that the number of positive containers for larvae is $69(\mathrm{CI}=33 \%)$ with a value of $\mathrm{DF}=8$ and is a high-density category with the type of container most commonly found with larvae, namely 58 used tires. $(27.8 \%)$. A total of 9 respondents $(39.1 \%)$ had good knowledge and 14 respondents $(60.9 \%)$ had poor knowledge of the causes and dangers of larvae. A total of 10 respondents (43.5\%) had a good attitude and as many as 13 respondents $(56.5 \%)$ had a bad attitude. In terms of action, only 1 respondent (4.3\%) seemed concerned and his actions were in the good category, whereas 22 respondents $(95.7 \%)$ had actions in the unfavourable category.

\section{Conflict of Interest}

The authors of the article declare no conflict of interest.

\section{Funding:}

The authors received no funding for conducting this study.

\section{References}

Alvarado-Castro, V., Paredes-Solis, S., Nava-Aguilera, E., Morales-Perez, A., AlarconMorales, L., Balderas-Vargas, N. A., et al. (2017). Assessing the effects of interventions for Aedes aegypti control: Systematic review and meta-analysis of cluster randomised controlled trials. BMC Public Health, 17(1), p. 21-38.

Al-Zurfi, B. M. N., Fuad, M. D. F., Abdelqader, M. A., Baobaid, M. F., Elnajeh, M., Ghazi, H. F., et al. (2015). Knowledge, attitude and practice of dengue fever and heath education programme among students of Alam Shah science school, Cheras, Malaysia. Malaysian Journal of Public Health Medicine, 15(2), p. 69-74.

Arsin, A. A. (2013). Epidemiology of Dengue Hemorrhagic Fever (DHF) in Indonesia. Makassar: Masagena Press.

Arsin, A. A., Ibrahim, E., Ane, R., \& Ishak, H. (2013). Analysis of Environmental Factors and Movement of PSN DBD Against Density of Aedes aegypti Mosquito Larva and DHF Incidence in DHF Endemic Areas in Makassar City. [online]. http://repository.unhas.ac.id/handle/123456789/11700 [accessed January 27, 2020].

Batara, A. S. (2018). Concept Model of Healthy Terminal Settings in South Sulawesi. Diss. 
Makassar: Universitas Hasanuddin.

Ibrahim, E., Manyullei, S., \& Sumarni., (2019). Study on the existence of Aedes aegypti larvae before and after the PSN DHF intervention in Pandang Village, Panakkukang District, Makassar City.Jurnal Nasional Ilmu Kesehatan (JNIK), 2(2), hal 109-120.

Indahsari, N. U. (2018). Public Transport Terminal Type B in Bengkayang. Jurnal Online Mahasiswa Arsitektur Untar, 6(1), hal.161-172

Ishak, H., Toding, N., Natsir, M. F., \& Amqam, H. (2018). Description of Aedes aegypti Larva Density Based on Mosquito Breeding Eradication Action in the Dengue Endemic Rappocini Sub-District Makassar. Proc. ICER-PH, Makassar, Indonesia. 26-27 Oktober 2018.

Kholid, A. (2012). Health Promotion with Behavioral Theory Approaches, Media, and Its Applications. Semarang: PT. Rajagrafindo Persada

Kumaran, E., Doom, D., Keo, V., Sokha, L., Sam, B. L., Chan, V., et al. (2018). Dengue knowledge, attitudes and practices and their impact on community-based vector control in rural Cambodia. PLoS Neglected Tropical Diseases, 12(2), p.1-16.

Ministry of Health of the Republic of Indonesia. (2016). Technical Guidelines for the Implementation of the 3M-Plus PSN with the Movement 1 Rumah 1 Jumantik. Jakarta: Kementerian Kesehatan Republik Indonesia.

Ministry of Health of the Republic of Indonesia. (2019). Indonesia Health Profile 2018. Jakarta: Kementerian Kesehatan Republik Indonesia.

Nani. (2017). Relationship between PSN Behavior and Aedes aegypti larvae at Pulang Pisau Port.Jurnal Berkala Epidemiologi, 5(1), hal.1-12.

Notoatmodjo, S. (2014). Behavioral Health Sciences. Jakarta: Rineka Cipta.

Purnianto, A., Hestiningsih, R., \& Kusariana, N. (2019). Relationship of Behavioral Factors with Existence of Aedes Aegypti in Buffer Area of Tanjung Intan Cilacap Port 2018. Journal Of Public Health For Tropical And Coastal Region (JPHTCR), 2(1), hal.1-10

Singh, R. K., Mittal P. K., Yadav, N. K., Gehlot, O. P \& Dhiman, R. C. (2011). Aedes aegyptiindices and KAP study in Sangam Vihar, South Delhi, during the XIX Commonwealth Games, New Delhi, 2010. Dengue Bulletin, 35(x), p.131-140.

Sudarmika, I. G. A. G., Maba, I. W., \& Widnyana, I. K. (2019). Relationship of Knowledge, Attitude and Infrastructure Means with Community Behavior in the Eradication Dengue Hemorrhagic Fever in Port of Padangbai Karangasem. International Journal of Contemporary Research and Review, 10(02), p.21376-21384. 